INTERNATIONAL JOURNAL OF ENGINEERING, SCIENCE AND TECHNOLOGY

www.ijest-ng.com www.ajol.info/index.php/ijest

(C)2015 MultiCraft Limited. All rights reserved

\title{
Comparative study on effect of blending, thermal barrier coating (LHR) on UOME biodiesel fuelled engine
}

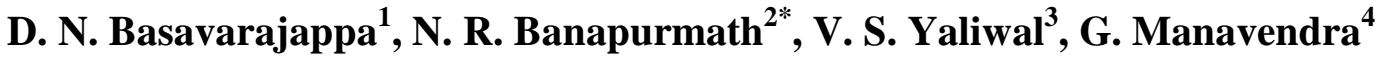 \\ ${ }^{l}$ GMIT, Davangere, Karnataka, INDIA \\ ${ }^{2}$ B.V.B. College of Engineering and Technology, Hubli, Karnataka, INDIA \\ ${ }^{3}$ S.D.M. College of Engineering and Technology, Dharwad, Karnataka, INDIA \\ ${ }^{4}$ BIET, Davangere, Karnataka, INDIA \\ *Corresponding author: e-mail: nr_banapurmath@rediffmail.com,nr_banapurmath@bvb.edu,Tel.: +919880726748.
}

\begin{abstract}
Growing concern regarding enhancement of engine performance associated with reduced emission levels as per EURO norms and to meet increasing energy requirements for the growing population aninterest has been created to study renewable and alternative fuels for internal combustion engines. Alternative fuels like biodiesels offer a very promising alternative to diesel oil since they are renewable and have similar properties to fossil diesel. Biodiesel derived from Uppage oil provide more suitable diesel substitute for compression ignition (CI) engines. Use of biodiesel in the CI engine lowers the engine's performance and increases the hydrocarbon and carbon monoxide emissions. But proper deployment of blending the biodiesel with diesel and adopting thermal barrier coatings (TBC) on engine piston, cylinder wall, and inlet and outlet valves to make the engine fully adiabatic will enhance the overall engine performance. In view of this experimental tests on diesel engine using Uppage oil methyl ester (UOME) and its blends in a TBC diesel engine using partially stabilized zirconia (PSZ) and aluminium oxide $\left(\mathrm{Al}_{2} \mathrm{O}_{3}\right)$ ceramic coated engine components were undertaken. The brake thermal efficiency, specific fuel consumption, carbon monoxide, unburned hydrocarbon and oxides of nitrogen emissions of both diesel and UOME and its blends were measured before and after coating and the results are compared. B20 fuelled biodiesel and PSZ coated engine provides almost comparable engine performance with acceptable emission norms. However, the longevity of TBC in diesel engines needs to be ensured before it can provide a sustained performance compared to blending option.
\end{abstract}

Keywords: Uppage oil, biodiesel, thermal barrier coating, low heat rejection

DOI: http://dx.doi.org/10.4314/ijest.v7i2.5

\section{Introduction}

Renewable and alternative fuels have numerous advantages compared to fossil fuels as they are renewable and biodegradable besides providing energy security and foreign exchange saving addressing environmental concerns, and socio-economic issues as well (Banapurmath et al., 2011, Yaliwal et al., 2014). In view of this, renewable fuels can be used as fuel for transportation and power generation and agricultural applications. Several investigators conducted exhaustive experiments on the use of various biodiesels of different origin in compression ignition (CI) engines for short and long term trial runs. Today, use of biodiesels derived from biomass is more reliant for addressing socio-economic values. Hence, renewable and sustainable source of energy is essential for economic and social development. The existing energy sources of energy from fossil fuels may not be adequate to meet the ever increasing energy demands. The diminishing and continuous increasing cost of petroleum resources associated with their alarming pollution levels from diesel engines has caused an interest in finding renewable, alternative and sustainable fuels to fossil diesel. Researchers have found that, the brake thermal efficiency of biodiesel operated single fuel engines were far lower compared to diesel operated engines and suggested that, this can be enhanced by improving the fuel properties, adopting different engine operating parameters or altering engine design etc. In order to address this, many researchers/scientists have proposed 
different solutions for enhancing the performance of a biodiesel operated engine (Agarwal and Rajamanoharan et al., 2009; Fontaras et al., 2009; Raheman et al., 2008; Atabani et al., 2013; Aydin and Bayindir, 2010; Banapurmath et al., 2009; Buyukkaya et al., 2006, 2007). India has implemented several policies towards renewable energy to reduce the huge amount of import bill of crude oil. In view of this, India needs to become self-reliance in energy sector (Agarwal 2009, Banapurmath et al 2011).

Direct use of vegetable oil or biodiesel in CI engine applications for longer duration of operation leads to some of the nonrecoverable problems. Therefore, they hinder the application of these fuels for long run trials (Agarwal and Agarwal 2009, Banapurmath et al., 2009; Atabani et al., 2013). Presence of high molecular weight fatty acids, high viscosity and low volatility character of raw vegetable oils are negatively affecting their utilisation as fuels in diesel engines. These effects can be eliminated or reduced through proper modification of engine (Banapurmath et al., 2009). Several investigators showed improved brake thermal efficiency and reduced exhaust smoke emissions with biodiesel blends (Bajpai and Sahoo, 2009; Sahoo et al., 2011; Aydin and Bayindir, 2010; Banapurmath et al., 2009; Singh et al., 2010; Atabani et al., 2013).

The effects of using neat cottonseed oil or its neat ME (methyl ester) bio-diesel, on the combustion behavior of a standard, high speed, direct injection (HSDI) has been reported. It was reported that ignition delay was not much affected, the fuel injection pressure diagrams were very slightly advanced accompanied with higher injection pressures, maximum cylinder pressures remained the same with the vegetable oil and slightly increased with the bio-diesel, and the cyclic irregularity was not affected with the bio-fuels remaining at the acceptable levels (Rakopoulos et al., 2006, 2007). Feasibility of biodiesel and their blends in diesel engine applications has been reported by several researchers. Lower $\mathrm{CO}, \mathrm{CO}_{2}, \mathrm{NO}_{\mathrm{x}}$, smoke emissions and lower brake thermal efficiency with biodiesel and their blends operation compared to diesel fuel operation has been reported (Singh et al 2010, Atabani et al., 2013). Lower and medium percentages of biodiesel can partially be substituted to the diesel fuel without any modifications in diesel engine (Aydin and Bayindir, 2010; Banapurmath et al., 2011). With HOME or Karanja biodiesel and their blends operation higher $\mathrm{CO}, \mathrm{NO}_{\mathrm{x}}$, smoke emissions and lower brake thermal efficiency compared to diesel fuel operation has been reported (Agarwal and Rajamanoharan et al., 2009, Banapurmath et al., 2008; Banapurmath et al., 2009).

Of the several technologies, thermal barrier coating (TBC) was conceived to improve the engine performance by deploying coatings on the engine components. Many studies have been conducted on the performance, structure and durability of the LHR engine (Rakopoulos and Giakoumis, 2006, 2007; Haşimoğlu et al., 2008; Banapurmath and Tewari, 2008; Hazar and Ugur, 2010; Jaichandar and Tamilporai, 2003; Buyukkaya et al., 2006; Aydin et al., 2014; Aydin and Sayin, 2015). Most of the researchers concluded that TBC act as insulation, reduces heat transfer, improves thermal efficiency and increases energy availability in the exhaust. Thermal barrier coatings are becoming important for thermal insulation of LHR engine components. Several studies named TBC as adiabatic or low heat rejection (LHR) facility and this concept in standard diesel engines has been adopted using different alternative fuels (Banapurmath and Tewari, 2008). Various TBC materials were used and include silicon carbide, silicon nitride, aluminium titanate, aluminium magnesium silicate, and ceramic such as aluminium oxide, partially stablilzedzerconia (PSZ). PSZ has been found to be quite desirable for adiabatic engine applications. This is because of its excellent insulating characteristics, strength, and thermal expansion characteristics. They are coated on piston, cylinder head, cylinder liner, and inlet and exhaust valves for fully adiabatic engine applications. The coating thickness varies from 1 to $2 \mathrm{~mm}$. Some important advantages of coated LHR engines are their improved fuel economy, reduced engine noise, and multi-fuel capability using low cetane fuels of biodiesels (Haşimoğlu et al., 2008; Banapurmath and Tewari, 2008; Hazar and Ugur, 2010; Aydin et al., 2014; Aydin and Sayin, 2015). The results of the investigations have been contradictory in nature. Most of them have concluded that insulation reduces heat transfer, improves thermal efficiency and reduces exhaust emissions. However, some experimental studies have indicated almost no improvement in thermal efficiency and claim that exhaust emissions deteriorate when compared with conventional diesel engines (Aydin et al., 2014; Aydin and Sayin, 2015).

In the present work, the main objectives of the work involves identifying suitable vegetable oil for biodiesel production i.e., UOME and its blends and their characterization and finally its utilization in a TBC engine. Hence an effort has been made to enhance the performance of the UOME fuelled diesel engine using two thermal barrier coatings as well as with normal uncoated engine when fuelled with UOME biodiesel and their blends derived from Uppage seed oil.

\section{Characterization of Uppage oil: Garcinia Cambogia (Uppage) oil as Biodiesel}

Amongst the many species, which can yield oil as a source of energy in the form of bio-fuel, "Garciniacambogia" (Uppagi) has been found to be one of the most suitable species in India being grown; it is $\mathrm{N}_{2}$-fixing trace. It is tolerant to water logging, saline and alkaline soils, and is grown in high rainfall region. Garcinia seeds contain 30 to $40 \%$ oil. Garciniacambogia belongs to the family species. The tree grows in forest and is a preferred species for controlling soil erosion and binding soil to roots because of its dense network of lateral roots. The seeds are largely exploited for oil extraction which is well known for its medicinal properties. So far there is no systematic organized collection of seeds. Mixture seeds consist of 95\% kernel and are reported to contain about 27.0 to $40 \%$ oil. The yield of oil is reported to be about 35 to $40 \%$ if mechanical expellers are used for the recovery of oil from the kernels. The crude oil is brown to creamy in color, which deepens on standing. It has a bitter taste and disagreeable odour. Fig. 1 shows the Uppage biomass and Fig. 2 shows the biodiesel preparation from Uppage oil. 


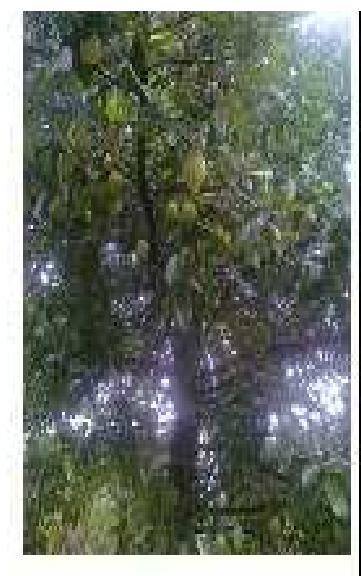

(a) Uppage Tree

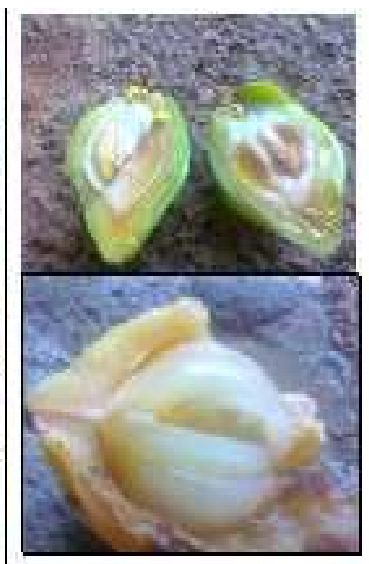

(b) Uppage Fruits

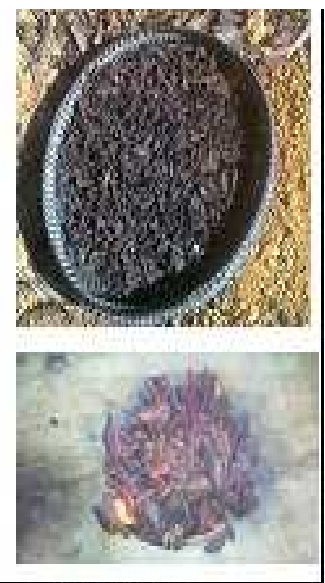

(c) Uppage Seeds

Figure1. Uppage biomass
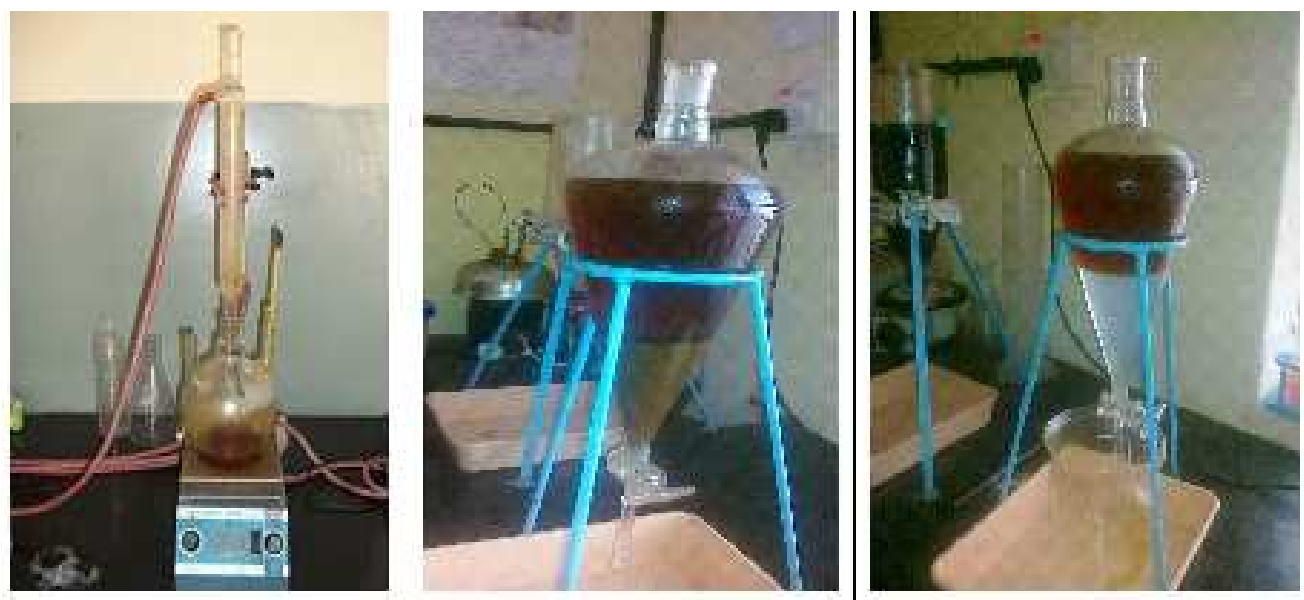

(a) 3-Neck conical glass bottle for transesterification, (b) Separation of Glycerine, (c) Washing with hot water

Figure2. Biodiesel preparation

In the present study, Diesel, and Uppage oil methyl ester (UOME) and its blends were used as injected fuels. UOME was obtained by transesterification process, where the triglycerides of Uppage oil were transferred to their corresponding monoesters by the reaction of methanol in the presence of sodium hydroxide catalyst. Table 1 shows the composition of Uppage oil, its fatty acids contribution, chemical formula, structure and their molecular weight with their chemical structure. The properties of UOME were determined experimentally and are summarized in Table 2.

Table 1 Fatty acid contribution of Uppage oil sample and its chemical structure

\begin{tabular}{|c|l|c|}
\hline Sl. No. & \multicolumn{1}{|c|}{ Fatty acid } & Fatty acid contribution \\
\hline 1 & Palmitic & $3.7-3.9$ \\
\hline 2 & Stearic & $2.4-8.9$ \\
\hline 3 & Lignoceric & --- \\
\hline 4 & Oleic & $44.5-71.5$ \\
\hline 5 & Lignoleic & $1.8-18.3$ \\
\hline 6 & Arachidic & $2.2-4.7$ \\
\hline 7 & Behenic & ---- \\
\hline 8 & Linolenic & ---- \\
\hline 9 & Eruceic & ---- \\
\hline
\end{tabular}

Table 2 Properties of fuels tested

\begin{tabular}{|c|l|c|c|c|}
\hline Sl. No. & Properties & Diesel & Uppage oil & UOME \\
\hline 1 & Chemical Formula & $\mathrm{C}_{13} \mathrm{H}_{24}$ & ---- & ---- \\
\hline 2 & Density $\left(\mathrm{kg} / \mathrm{m}^{3}\right)$ & 840 & 915 & 860 \\
\hline 3 & Calorific value $(\mathrm{kJ} / \mathrm{kg})$ & 43,000 & 38950 & 40727 \\
\hline 4 & Viscosity at $40^{\circ} \mathrm{C}(\mathrm{cSt})$ & $2-5$ & 44.85 & 5.2 \\
\hline
\end{tabular}


Table 2 (cont'd) Properties of fuels tested

\begin{tabular}{|c|l|c|c|c|}
\hline Sl. No. & Properties & Diesel & Uppage oil & UOME \\
\hline 5 & Flashpoint $\left({ }^{\circ} \mathrm{C}\right)$ & 75 & 210 & 178 \\
\hline 6 & Cetane Number & $45-55$ & 40 & 45 \\
\hline 7 & Carbon Residue $(\%)$ & 0.1 & 0.66 & ---- \\
\hline 8 & Cloud point & -2 & ---- & 18 \\
\hline 9 & Pour point & -5 & ---- & 21 \\
\hline 10 & Carbon residue & 0.13 & 0.55 & 0.01 \\
\hline 11 & Molecular weight & 181 & & 227 \\
\hline 12 & Auto ignition temperature $\left({ }^{\circ} \mathrm{C}\right)$ & 260 & & 470 \\
\hline 13 & Ash content $\%$ by mass & 0.57 & & 0.01 \\
\hline 14 & Oxidation stability & High & Low & Low \\
\hline 15 & Sulphur Content & High & No & No \\
\hline
\end{tabular}

\section{Heat Release Rate Calculation}

The heat release rate at each crank angle was calculated by using a first law analysis of the average pressure versus crank angle variation obtained from 100 cycles using the following expression given below:

$$
\text { Qapp }=\frac{\gamma}{\gamma-1}[P d V]+\frac{1}{\gamma-1}[V d p]+Q \text { wall }
$$

where,

$\mathrm{Q}_{\text {app }} \quad$ - Apparent heat release rate $(\mathrm{J})$

$\gamma_{-}$- Ratio of specific heats $\mathrm{C}_{\mathrm{p}} /\left(\mathrm{C}_{\mathrm{p}}-\overline{\mathrm{R}}\right)$

$\overline{\mathrm{R}} \quad$ - Gas constant in $(\mathrm{J} / \mathrm{kmol}-\mathrm{K})$

$\mathrm{C}_{\mathrm{p}} \quad$ - Specific heat at constant pressure $(\mathrm{J} / \mathrm{kmol}-\mathrm{K})$

$\mathrm{V} \quad$ - Instantaneous volume of the cylinder $\left(\mathrm{m}^{3}\right)$

$\mathrm{P} \quad$ - Cylinder pressure (bar)

$\mathrm{Q}_{\text {wall }}$ - Heat transfer to the wall (J)

$$
Q w a l l=h \times A \times[T g-T w]
$$

\section{Experimental Set-Up}

Experimental investigations were conducted on a four stroke single cylinder direct injection water-cooled compression ignition (CI) engine (Fig. 3) using TBC or LHR facility and UOME blends in the proportion of B20, B40, B60 and B100. The specifications of the engine are given in Table 3. The engine was operated at a rated speed of $1500 \mathrm{r} / \mathrm{min}$. The engine was having a conventional fuel injection system and its specification was three holes of $0.3 \mathrm{~mm}$ diameter with a spray angle of $120^{\circ}$ apart following an injector opening pressure of $205 \mathrm{bar}(20500 \mathrm{kPa})$ along with static injection timing $23^{\circ}$ before top dead centre (bTDC). The engine has regular governor used to control the engine speed. The engine had hemispherical combustion chamber with overhead valves operated through push rods. Cooling of the engine was accomplished by circulating water through the jackets of the engine block and cylinder head. Experiments were conducted under a thermal steady-state condition of the engine with an inlet cooling water temperature of $80^{\circ} \mathrm{C}$. A piezoelectric pressure transducer was mounted flush with the cylinder head surface to measure the cylinder pressure. The exhaust gas emissions were measured using an exhaust gas analyser. In order to study the effect of TBCs on biodiesel engine performance two TBCs of $\mathrm{PSZ}$ and $\mathrm{Al}_{2} \mathrm{O}_{3}$ were selected. Figure 3 shows the piston and cylinder head coated with PSZ to obtain an LHR coating. Figure 4 shows the piston and cylinder head coated with $\mathrm{Al}_{2} \mathrm{O}_{3}$ to obtain another LHR coating.

Table 3 Specifications of the engine

\begin{tabular}{|l|l|l|}
\hline SI No & Parameters & Specification \\
\hline 1 & Type of engine & $\begin{array}{l}\text { Kirloskar make Single cylinder four stroke direct injection } \\
\text { diesel engine }\end{array}$ \\
\hline 2 & Nozzle opening pressure & 200 to 205 bar (20000 to 20500 kPa) \\
\hline 3 & Rated power & $5.2 \mathrm{KW} \mathrm{(7} \mathrm{HP)} \mathrm{@} \mathrm{1500} \mathrm{RPM}$ \\
\hline 4 & Cylinder diameter (Bore) & $87.5 \mathrm{~mm}$ \\
\hline 5 & Stroke length & $110 \mathrm{~mm}$ \\
\hline 6 & Compression ratio & $17.5: 1$ \\
\hline
\end{tabular}




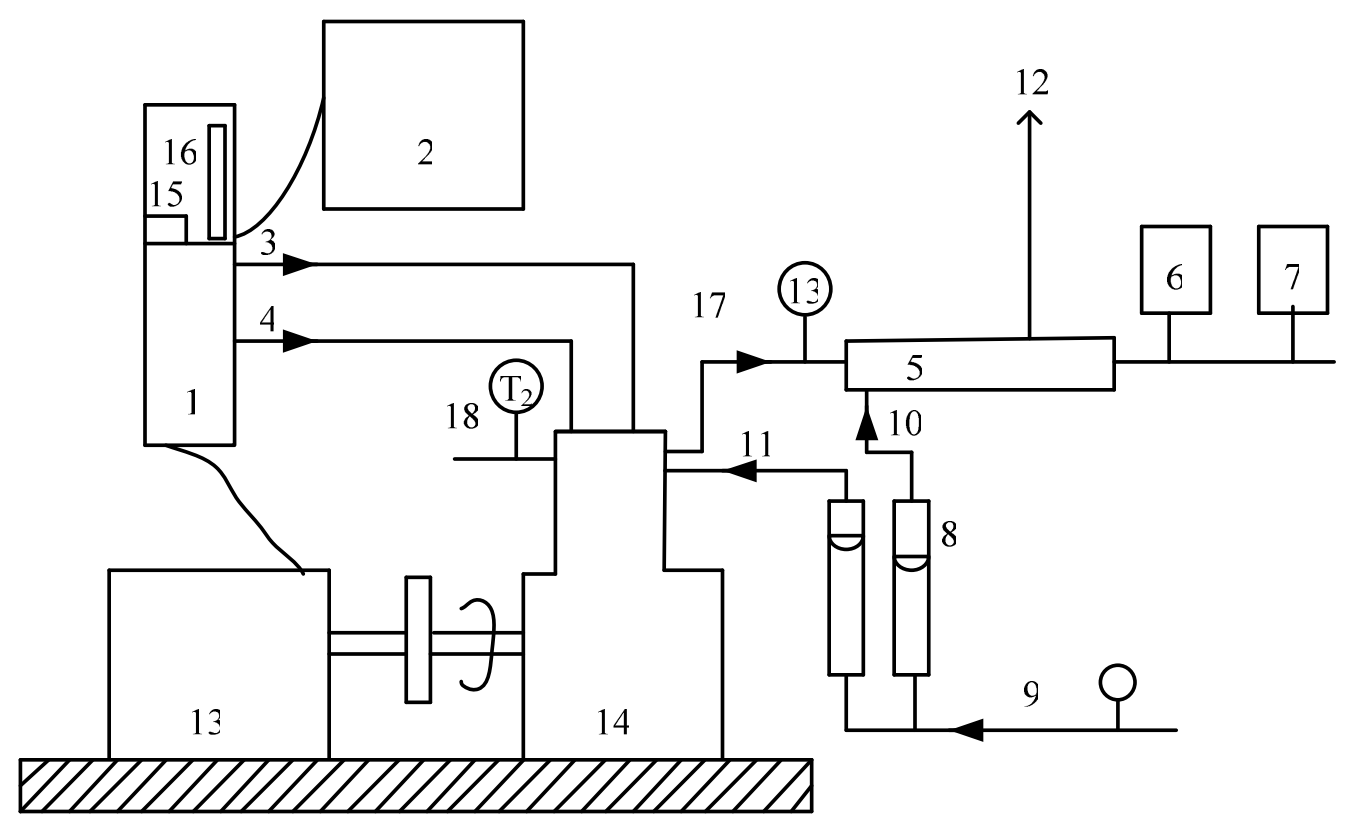

1- Control Panel, 2 - Computer system, 3 - Diesel flow line, 4 - Air flow line, 5 - Calorimeter, 6 - Exhaust gas analyzer, 7 - Smoke meter, 8 - Rota meter, 9, 11- Inlet water temperature, 10 - Calorimeter inlet water temperature,12 - Calorimeter outlet water temperature, 13 - Dynamometer, 14 - CI Engine, 15 - Speed measurement,16 - Burette for fuel measurement, 17 - Exhaust gas outlet, 18 - Outlet water temperature, T1- Inlet water temperature, T2 - Outlet water temperature, T3 - Exhaust gas temperature.

Figure3. Overall view of the Experimental setup

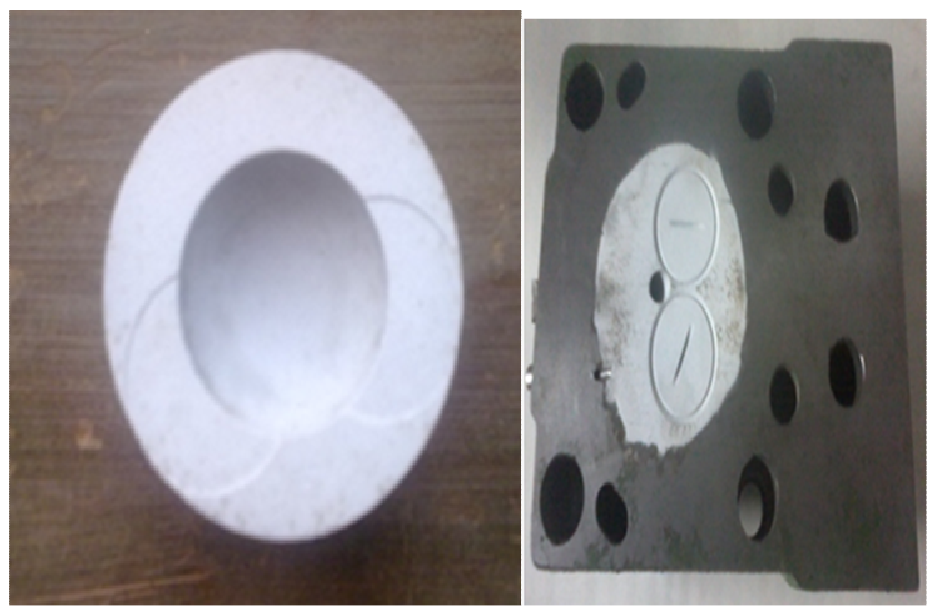

Piston coated with PSZ

Cylinder head coated with PSZ

Figure4. PSZ coated piston and cylinder head

All measurements were done when engine was attained steady state. For each load, five readings were generated to ensureaccuracy of the data recorded and careful experimental arrangements were made to make it possible to obtain consistent and repeatable measurements. In order to reduce the error in the measurement of emissions, five readings were recorded and only their averages are presented in the graphs. The uncertainty of the measured parameters was estimated with confidence limits of $\pm 2 \sigma$ ( $95.45 \%$ of the measured data lie within the limits of $\pm 2 \sigma$ around the mean). The percentage uncertainty of the measured parameters was estimated using the following relation:

$$
\Delta x i=\frac{2 \sigma x_{i}}{x_{i}} \times 100
$$




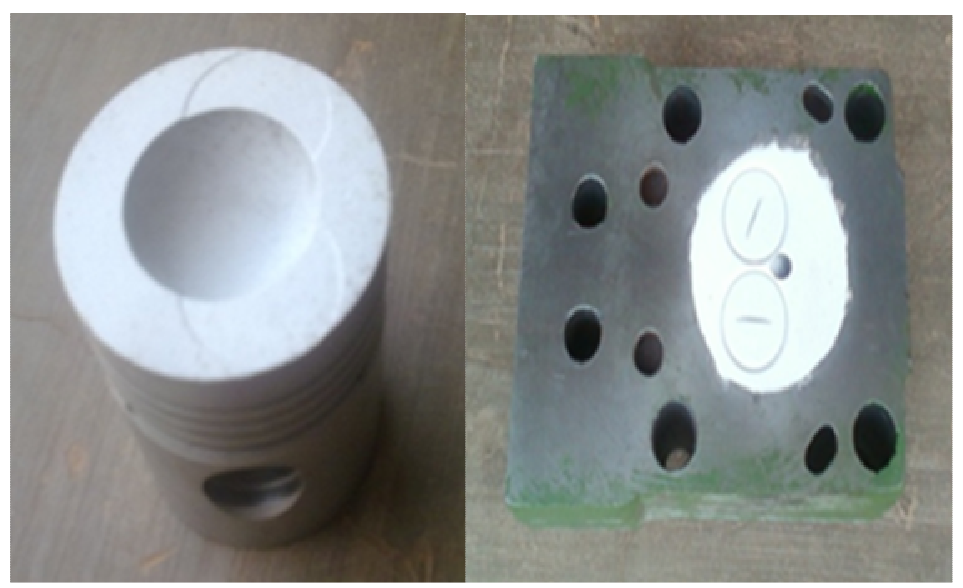

Piston coated with $\mathrm{Al}_{2} \mathrm{O}_{3}$ Cylinder head coated with $\mathrm{Al}_{2} \mathrm{O}_{3}$

Figure5. $\mathrm{Al}_{2} \mathrm{O}_{3}$ coated piston and cylinder head

\section{Results and Discussions}

In this section, experiments carried out on diesel engine with LHR (PSZ and $\mathrm{Al}_{2} \mathrm{O}_{3}$ ceramic coatings) facility using UOME and its blends is presented. In the present work, blending with diesel in different such as B20, B40, B60 and B100 were used. Base line readings and test trial readings were also generated with existing uncoated diesel engine for the comparative study. In the next phase engine operation using UOME and its blends operation was compared and analysed with base line reading.

\subsection{Effect of biodiesel and their blends on the performance of diesel Engine}

The engine is operated on biodiesels of UOME and their blends of diesel under variable load conditions and compared with diesel engine performance. Diesel operation was performed injection timing of $23^{\circ} \mathrm{BTDC}$, compression ratio of 17.5 and injection pressure of 205 bar $(205000 \mathrm{kPa}$ ) has been selected for the engine operation. Engine operation with UOME refers to optimized engine conditions with IOP of $230 \mathrm{bar}$, IT of $19^{\circ} \mathrm{BTDC}$, and compression ratio of 17.5 and injector with 4 holes. While all other blends run with diesel engine conditions of IOP of 205 bar, IT of $23^{\circ} \mathrm{BTDC}$, and injector with 3 holes.

\subsubsection{Performance Parameters:}

Variation of brake thermal efficiency w.r.t brake power for respective biodiesel and their blends with diesel is presented in Fig. 2. There is a steady increase in efficiency as load increases. The brake thermal efficiency with B20 blend operation is closer to diesel operation. Further it is observed that there was decreased brake thermal efficiency when biodiesel proportion in the blend increases. Poor combustion characteristics of the blends due improper atomization due to increased viscosity of blend caused by the more addition of UOME is responsible for this trend. The B20 blend of UOME showed better performance compared to that of other blends tested. Diesel being common properties and respective biodiesel in the blend are obviously responsible for this behaviour. The maximum brake thermal efficiency value observed with B20, B40, B60 and B100 operation were found to be $26.55 \%, 26 \%$ and $25.00 \%$ at $80 \%$ load compared to $27.57 \%$ with diesel.

\subsubsection{Emission parameters}

Effect of blends on the smoke emission w.r.t different loads for various fuel combinations is shown in Fig.6. It is observed that smoke emission levels were increased with increase in load. Increased fuel consumption with increase in load may be responsible for this observed trend. Results were showed lower smoke levels for diesel operation compared to UOME. However, higher biodiesel proportion in the blend leads to increased smoke levels. The possible reason for this behaviour is mainly due to increased viscosity of the blends caused by the addition of more biodiesel. The greater smoke opacity for UOME and their blends is mainly attributed to emission of higher molecules of $\mathrm{HC}$ and particulate due to incomplete combustion. Presence of free fatty acids in an UOME, lower energy content, improper mixing of fuel and air due to improper spray pattern and lower combustion temperature are also responsible for this trend. Further, it is seen that B20 operation resulted in lower smoke levels compared to other blends tested. Addition of lower biodiesel improves the combustion due to presence of oxygen in the biodiesel leads to improved combustion and soot oxidation. The smoke levels for B20, B40, B60 and B100 operation were found to be 26.55 HSU, 26 HSU \% and $25.00 \mathrm{HSU}$ at $80 \%$ load compared to $27.57 \mathrm{HSU}$ with diesel.

Variations in $\mathrm{HC}$ and $\mathrm{CO}$ emission levels w.r.t load for various fuel combination is presented in Figure 7 and 8. $\mathrm{HC}$ and $\mathrm{CO}$ emissions were increased with increase in load. Diesel operation resulted in lower HC and CO levels compared to biodiesel and their blends. Biodiesel has higher viscosity and higher fatty acids leads to improper fuel and air mixing caused by the improper spray pattern. Lower oxidation rate caused by reduced volumetric efficiency is also responsible for the observed trend. Lower premixed combustion during ignition delay may also affect the combustion. Hence, biodiesel and their blends resulted in lower combustion temperature compared to diesel leading to higher $\mathrm{HC}$ and $\mathrm{CO}$ levels. However, B20 resulted acceptable $\mathrm{HC}$ and $\mathrm{CO}$ levels compared to other blends tested. Therefore, it can be concluded that properties of the fuel used and amount of oxygen taking 
part in the combustion plays a significant role in reducing such emission levels during combustion. The HC emissions with B20, B40, B60, B80 and B100 operation were found to be $784 \mathrm{ppm}, 772 \mathrm{ppm}$ and $770 \mathrm{ppm}$ at $80 \%$ load compared to $790 \mathrm{ppm}$ with diesel operation. Similarly CO emissions with B20, B40, B60, B80 and B100 operation were found to be $784 \mathrm{ppm}, 772 \mathrm{ppm}$ and $770 \mathrm{ppm}$ at $80 \%$ load compared to $790 \mathrm{ppm}$ with diesel operation.

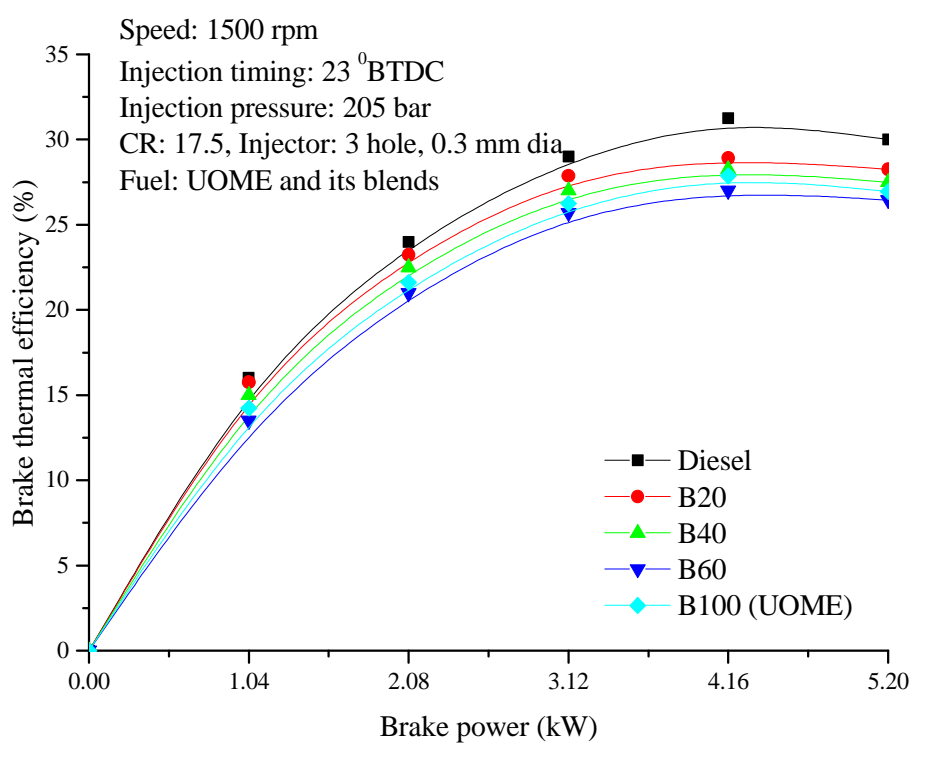

Figure6. Variation of brake thermal efficiency for UOME and their blends

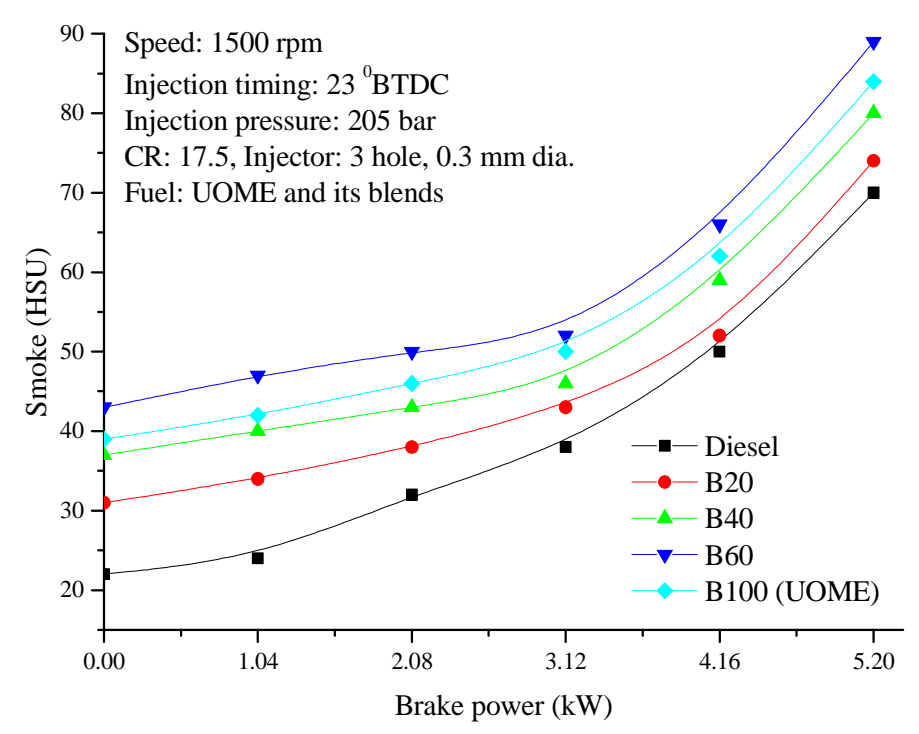

Figure7. Variation of smoke opacity for UOME and their blends

Variations in $\mathrm{NO}_{\mathrm{x}}$ levels w.r.t load for various fuel combination is presented in Figure 6. NOx emissions were increased with increase in load. Diesel operation resulted in higher NOx levels compared to biodiesel and their blends. Biodiesel has higher viscosity and higher fatty acids leads to lower premixed combustion phase resulting reduced NOx emission levels. Hence, biodiesel and their blends resulted in lower rate of heat release during the premixed combustion phase compared to diesel leading to lower NOx levels. However, B20 resulted in sligtly higher NOx emissions compared to other blends tested. From the results it is claimed that properties of the fuel plays a significant role during burning of fuel. The NO emissions with B20, B40, B60, B80 and B100 operation were found to be $784 \mathrm{ppm}, 772 \mathrm{ppm}$ and $770 \mathrm{ppm}$ at $80 \%$ load compared to $790 \mathrm{ppm}$ with diesel operation. 


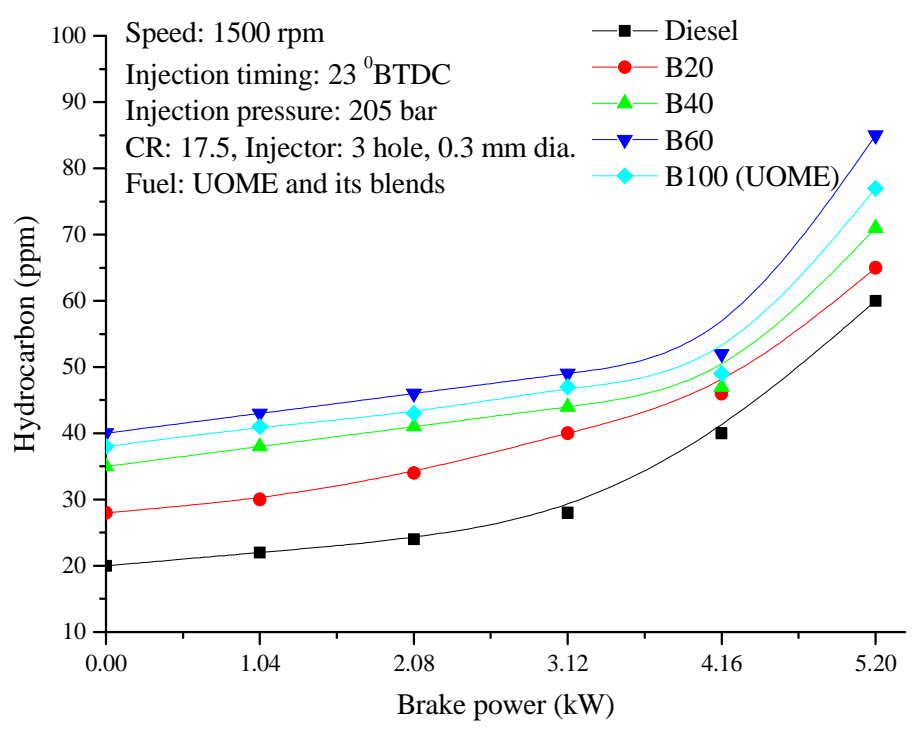

Figure8. Variation of HC emission for UOME and their blends

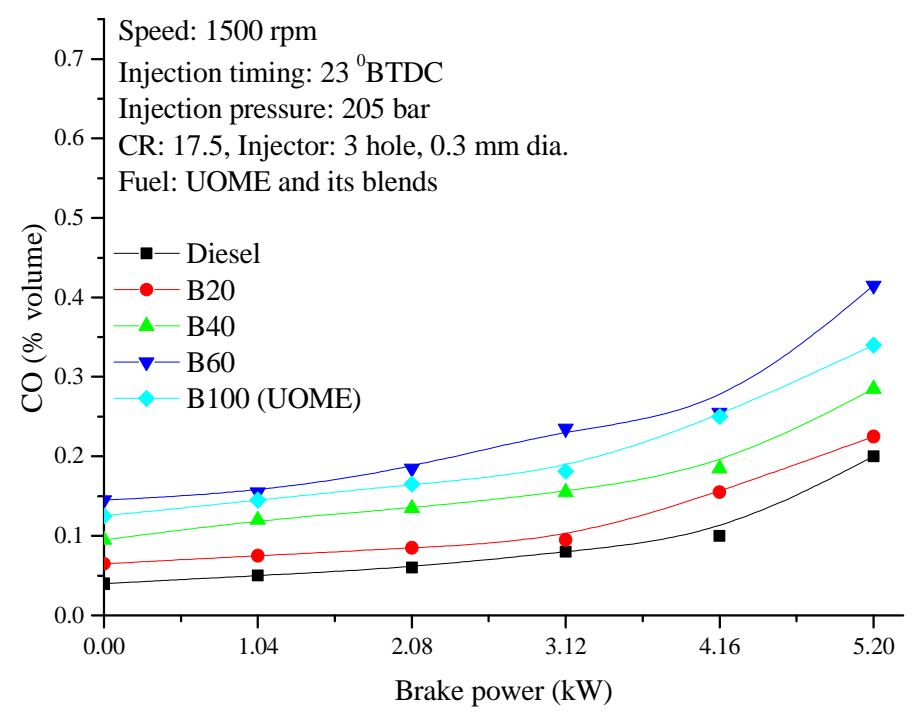

Figure 9. Variation of $\mathrm{CO}$ emission for UOME and their blends

5.1.3 Combustion parameters:

This section discusses the various combustion parameters with UOME operation in TBCs mode of engine operation. The effect of brake power on ignition delay for respective biodiesel and their blends with diesel at $80 \%$ load is shown in Fig.10. The ignition delay is calculated based on the static injection timing. Biodiesel and their blends showed longer ignition delays as compared to diesel due to their lower cetane number and energy content. Diesel showed lower ignition delay compared to biodiesel and their blends. 


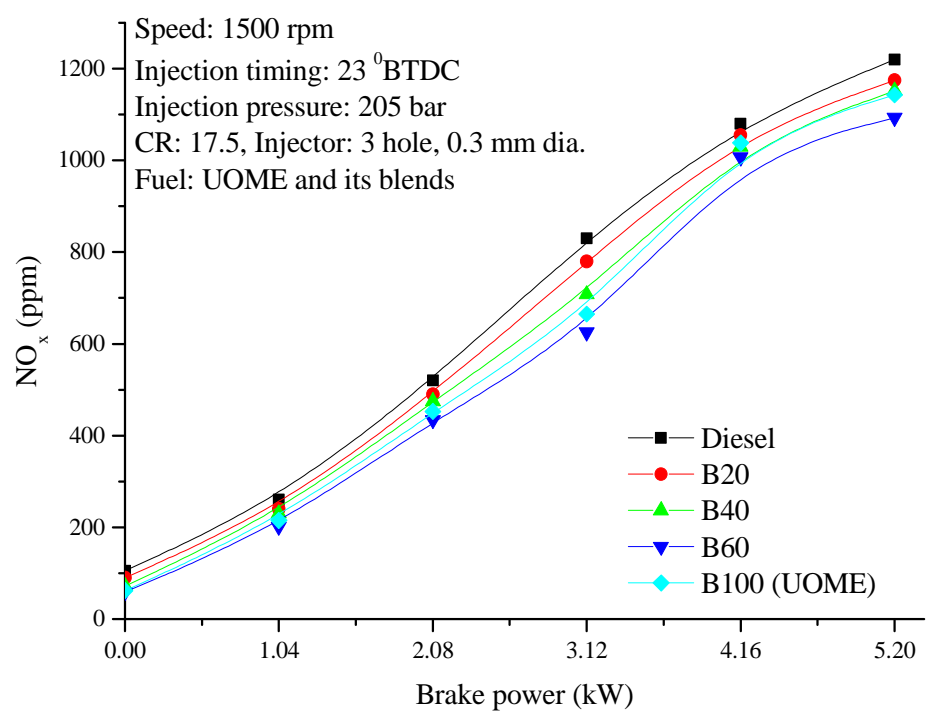

Figure10. Variation of NOx emission for UOME and their blends

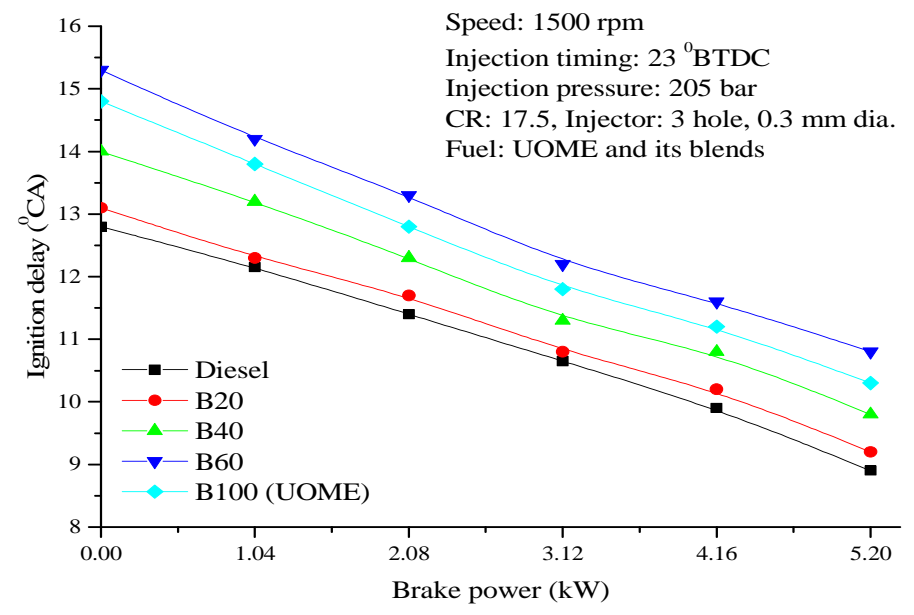

Figure11. Variation of ignition delay for UOME and their blends

The combustion duration shown in Fig. 11 was calculated based on the duration between the start of combustion and $90 \%$ cumulative heat release. The combustion duration increases with increase in the power output with all the fuels. This is due to increase in the quantity of fuel injected. Higher combustion duration is observed with biodiesel and their blends than diesel due to longer diffusion combustion phase. The B20 blend of HnOME $\left(\mathrm{B}_{\mathrm{HnOME}} 20\right)$ showed lower combustion duration when compared to that of COME ( $\left.\mathrm{B}_{\mathrm{COME}} 20\right)$ and RuOME $\left(\mathrm{B}_{\mathrm{RuOME}} 20\right)$. Diesel being common the properties of the respective biodiesel are obviously responsible for this behaviour.

The cylinder pressure crank angle history is obtained for 100 cycles for respective biodiesel and their blends with diesel at $80 \%$ load and the average pressure variation with crank angle is shown in Fig. 12. The B20 blend of UOME showed higher peak pressure when compared to that of its other blends. Diesel quantity being higher improves cetane number and calorific value of the B20 blend and the improved combustion results in higher peak pressure. 


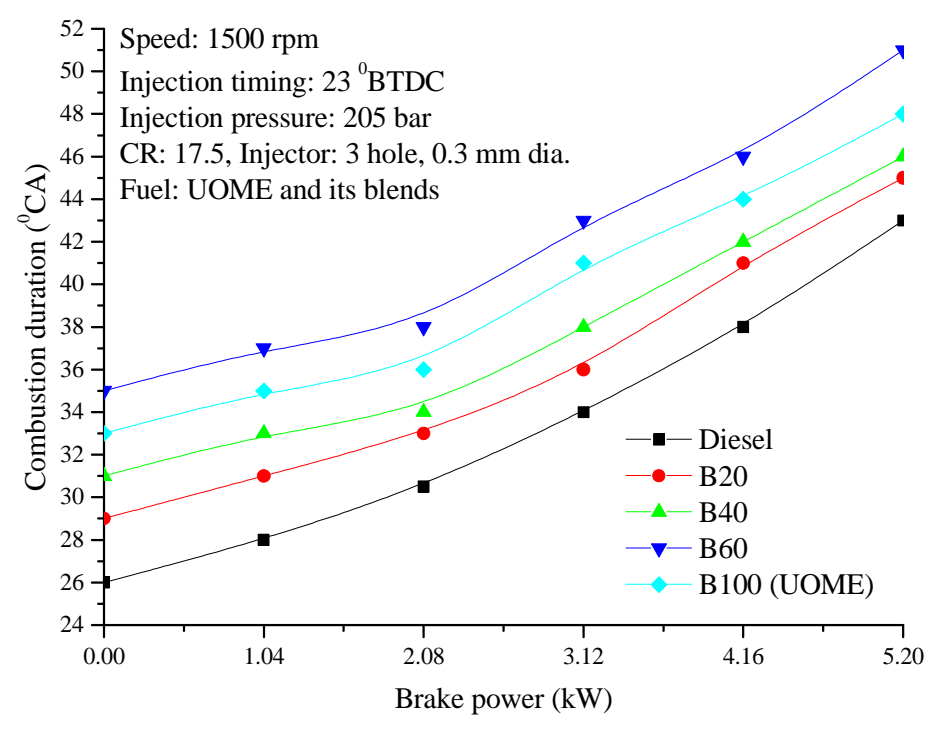

Figure12. Variation of combustion duration for UOME and their blends

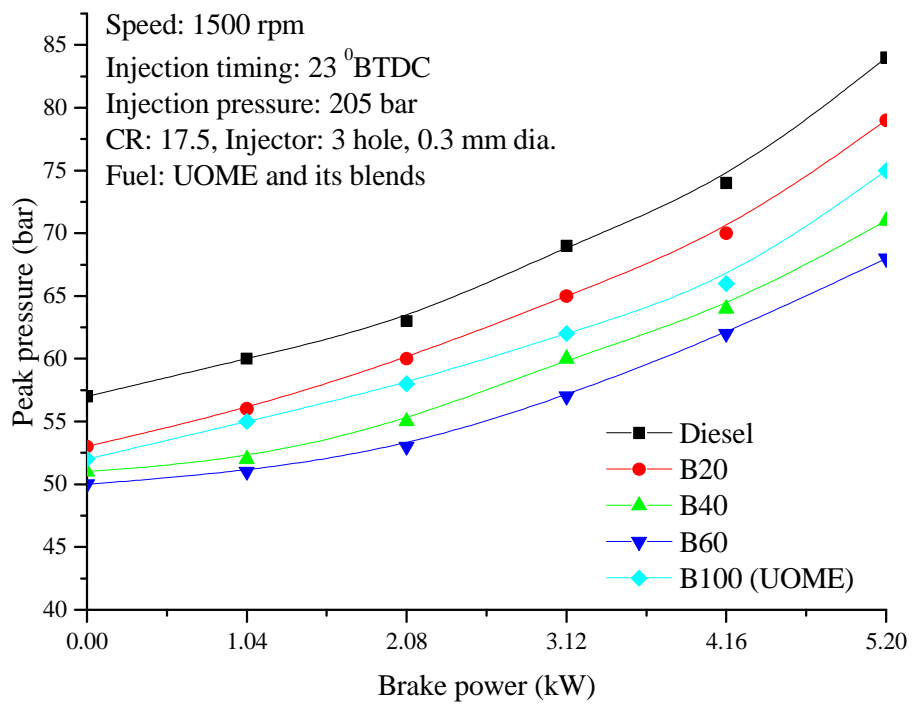

Figure13. Variation of Peak pressure for UOME and their blends

5.2 Effect of Thermal barrier coating on the Performance of the biodiesel Engine:

5.2.1 Performance parameters:

Effect of thermal barrier coatings (TBCs) on the biodiesel engine performance using PSZ and $\mathrm{Al}_{2} \mathrm{O}_{3}$ onbrake thermal efficiency w.r.t various fuel combinations is presented in Figure 13. It is seen that biodiesel operation resulted in lower brake thermal efficiency, but it can be improved by reducing the heat transfer rates through the cylinder and coolant. Such a method called TBC is used for the testing of fuel behaviour during combustion. Investigations with TBC diesel engine showed improved thermal efficiency with UOME biodiesel operation. It could be attributed to reduced heat transfer rate with TBC engine compared to normal engine operation. Reduced heat transfer increases the combustion temperature, and facilitates to burn the comparatively viscous UOME fuel better. Further, coating material such as PSZ showed better thermal efficiency compared to $\mathrm{Al}_{2} \mathrm{O}_{3}$ operation. UOME being common, the TBC material properties plays a significant role on the combustion behaviour of UOME. 


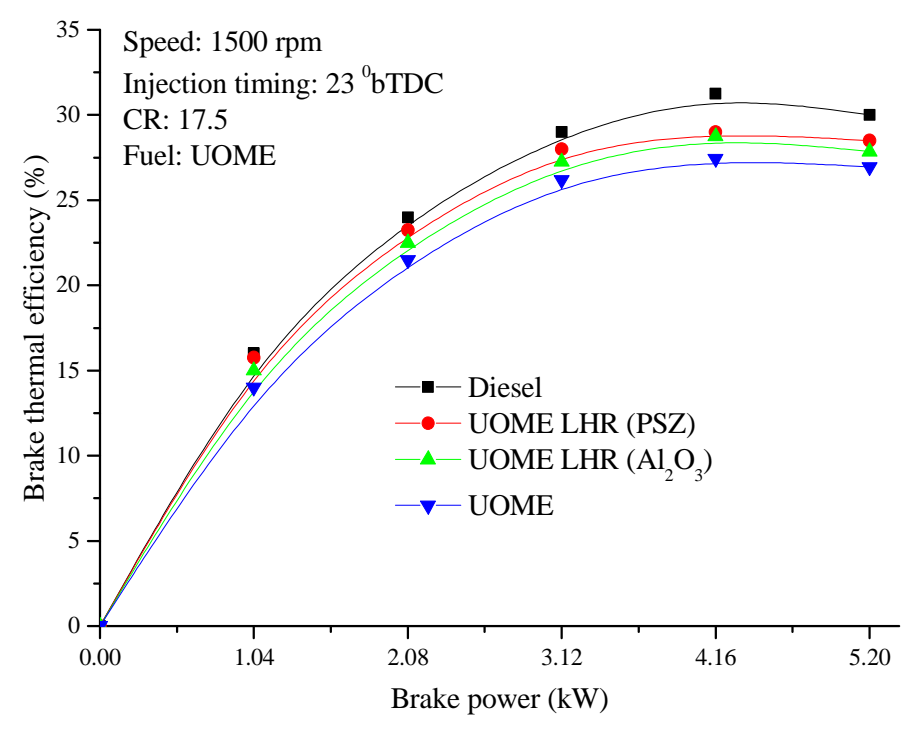

Figure14. Variation of brake thermal efficiency for UOME with TBC

5.2.2 Emission parameters:

Smoke opacity:

The results of smoke opacity related to different engine loads and TBCs are presented in Figure 14. Formation of smoke is basically a process of conversion of molecules of $\mathrm{HC}$ fuels into particles of soot.Higher smoke levels from UOME operation is mainly caused by its heavier molecular which results into incomplete combustion. This could be due to its combined effect of poor atomization, irreversibility and lower calorific value as well. Resultsshowed that smoke opacity decreases with use of TBCs for UOME due to better combustion caused by enhanced soot oxidation. Higher combustion temperature causing increased flame velocity resulting in better conversion of fuel energy in to work is also responsible for this observed trend(Banapurmathet al. 2008). However, UOME operation with PSZ coating further reduces smoke emission levels compared to $\mathrm{Al}_{2} \mathrm{O}_{3}$ operation. It could be due to more complete burning of the fuel combination caused by better thermal properties of PSZ, better soot oxidation associated with addition of more oxygen in presence of high combustion temperature.

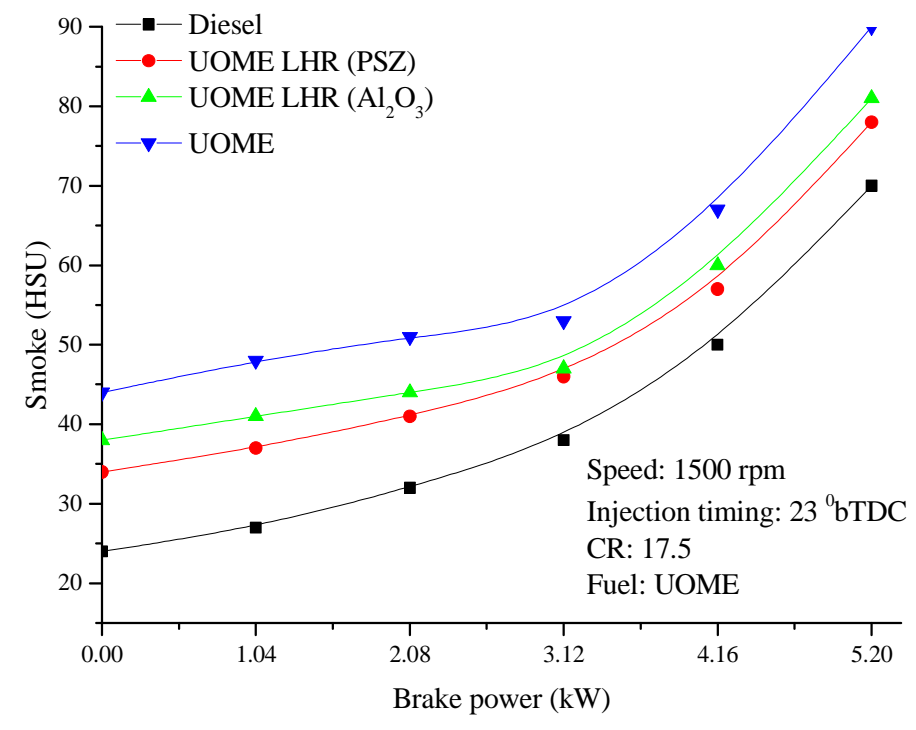

Figure15. Variation of smoke opacity for UOME with TBC

$\mathrm{HC}$ and $\mathrm{CO}$ emissions

$\mathrm{HC}$ and $\mathrm{CO}$ emission levels for different engine loads with biodiesel engine coated TBCs are shown in Figures 15 and 16.Lower $\mathrm{HC}$ and $\mathrm{CO}$ emission levels for diesel operation compared to UOME were observed.Improper spray pattern of the 
injected UOME inside the combustion chamber results into incomplete combustion with lowered BTE. The lower volatility of UOME further results into lower combustion temperature and increased heat loss to cooling and surroundings resulting into higher unburned $\mathrm{HC}$ and $\mathrm{CO}$ emission levels. For the same biodiesel, lower $\mathrm{HC}$ and $\mathrm{CO}$ levels were observed with $\mathrm{TBC}$ operation compared to normal engine operation. Use of oxygenated fuels in presence of high combustion temperature promotes better combustion i.e. oxygen availability in biodiesel is comparatively higher and coupled with engine operation of TBC coating; carbon easily combines with oxygen and lowers both $\mathrm{HC}$ and $\mathrm{CO}$ emission levels. This is the reason for $\mathrm{HC}$ and $\mathrm{CO}$ emission reduction with TBC operation. Therefore, it is observed that use of TBC significantly lowers both $\mathrm{HC}$ and $\mathrm{CO}$ emissions. Further reductions in emission levels were observed for UOME when engine was operated on PSZ coating compared to $\mathrm{Al}_{2} \mathrm{O}_{3}$ operation.Itcouldbedue to the fact that engine operation with PSZ coating contributes positively tohigher combustion efficiency.

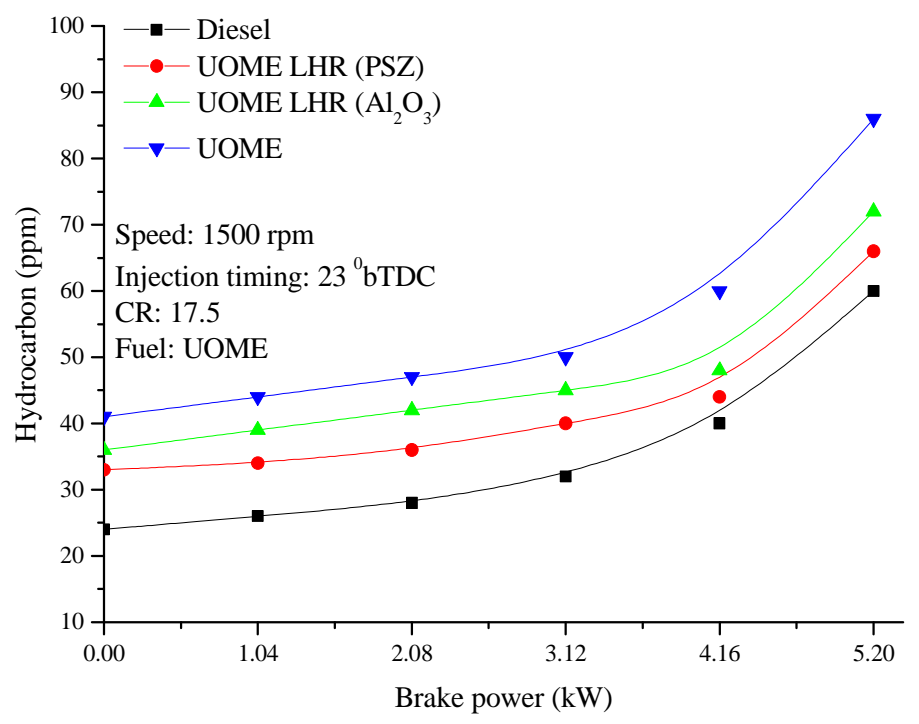

Figure16. Variation of HC for UOME with TBC

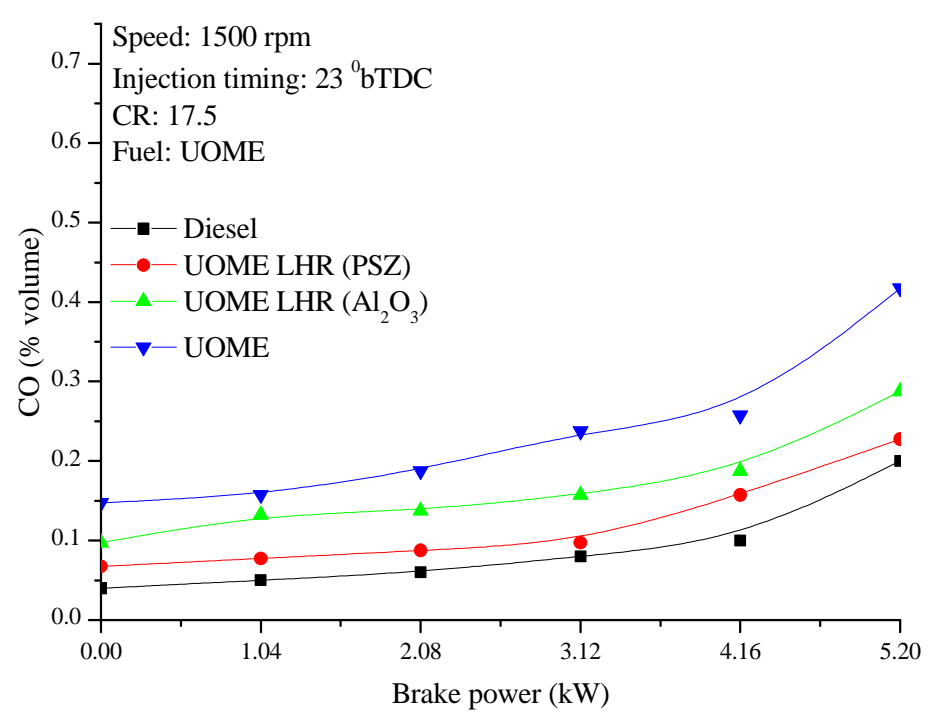

Figure17.Variation of COfor UOME with TBC

Nitric oxide emission:

NOx emission is lower with UOME compared to diesel operation (Figure 17). Lower combustion rates due to increased ignition delay and EGT for UOME operation adds to this behaviour. However, use of TBC resulted in marginally increased NOx emissions than the normal engine operated on the same fuels. Improved combustion of the biodiesel-air mixture in TBC engine during premixed combustion phase is responsible for this observed trend. Increased gas and cylinder wall temperature causes an increase in $\mathrm{NO}_{\mathrm{X}}$ emission compared to uncoated engine. Factors facilitating and accelerating the reaction between oxygen and 
nitrogen, increases the $\mathrm{NO}_{\mathrm{X}}$ formation.However, UOME operation with $\mathrm{TBC}$ resulted in NOx emission levels marginally nearer compared to diesel operation. It could be attributed to better burning of the fuel resulting in slightly higher cylinder pressure due to improved premixed combustion phase. It is observed that for the same fuel and operating conditions, UOME operation with PSZ coating resulted in slightly higher NOx emission levels compared to $\mathrm{Al}_{2} \mathrm{O}_{3}$ operation. It could be attributed to reduced heat transfer rates and better thermal properties of PSZ when compared to $\mathrm{Al}_{2} \mathrm{O}_{3}$ operation. In general, Diesel operation recorded higher NOxemission levels compared to UOME operation.

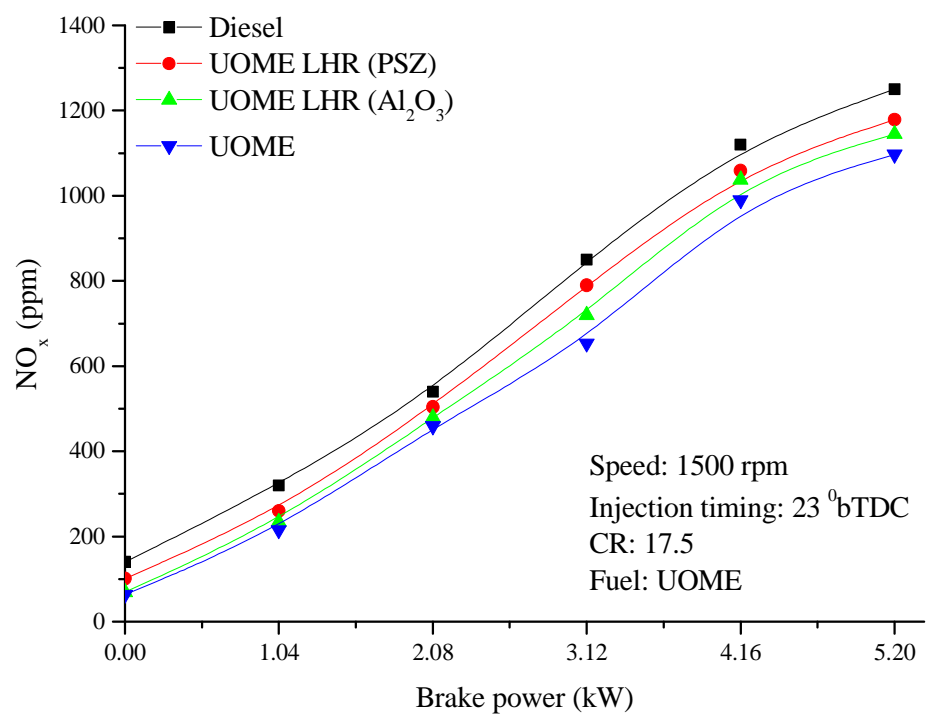

Figure18. Variation of NOx for UOME with TBC

\subsubsection{Combustion parameters:}

The effect of PSZ on ignition delay for UOME biodiesel tested is shown in Figure 18. The ignition delay is calculated based on the static injection timing. Diesel showed lower ignition delay compared to UOME biodiesels. Higher viscosity and lower volatility of the biodiesel leads to poor atomization and mixture preparation with air during the ignition delay period. However, increased gas temperature in thermal barrier coated engines improves combustion with shortened ignition delay and affects both chemical and physical reactions positively. From the Figure, it is observed that UOME with PSZ resulted in lower ignition delay compared to $\mathrm{Al}_{2} \mathrm{O}_{3}$ operation.

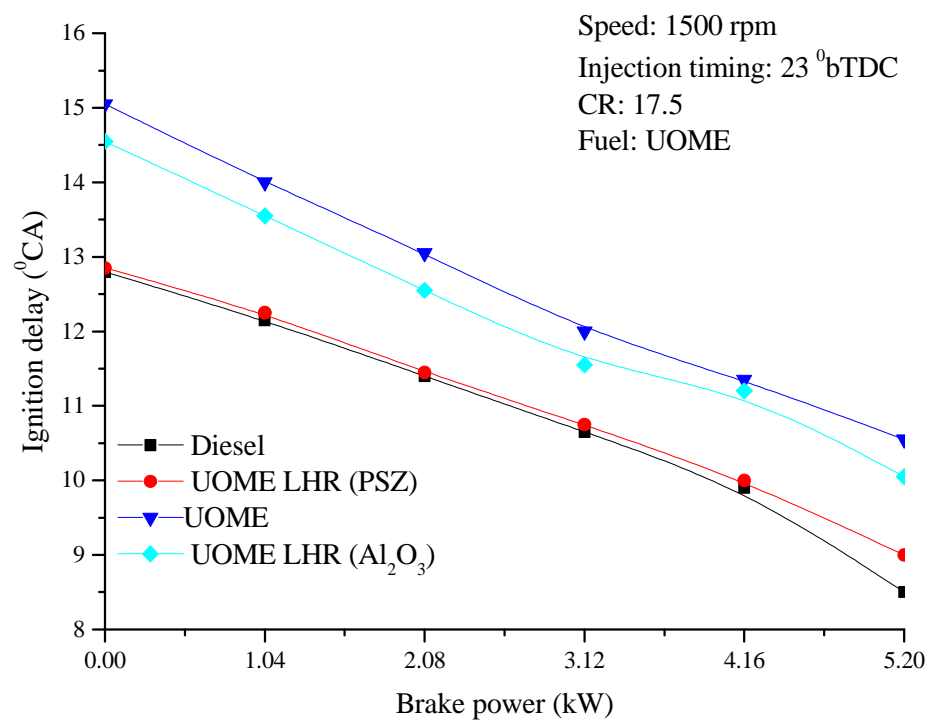

Figure19.Variation of ignition delay for UOME with TBC 
The combustion duration shown in Figure 19 was calculated based on the duration between the start of combustion and $90 \%$ cumulative heat release. It was observed that the combustion duration increases with increase in the power output with all the fuels tested. This is due to increase in the quantity of fuel injected. Combustion duration for UOMEwere found to be longer compared to diesel due to its longer diffusion combustion phase. However, it could be lowered with increased cylinder temperature by incorporating LHR facility. With the PSZ the combustion duration was observed to be shortened compared to $\mathrm{Al}_{2} \mathrm{O}_{3}$ operation.

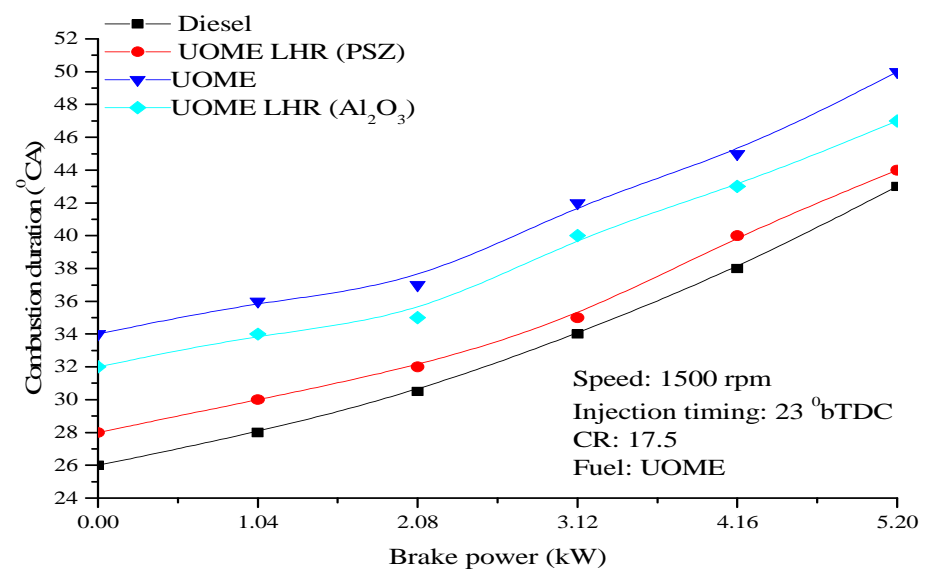

Figure20.Variation of combustion duration for UOME with TBC

The cylinder pressure crank angle history is obtained for 100 cycles for respectiveUOME at $80 \%$ load and the average pressure variation with crank angle is shown in Fig. 20. The UOME with TBCs showed higher peak pressure when compared to that of normal engine operation. Reduced heat loss from the engine improved engine efficiency in TBC engine operation.

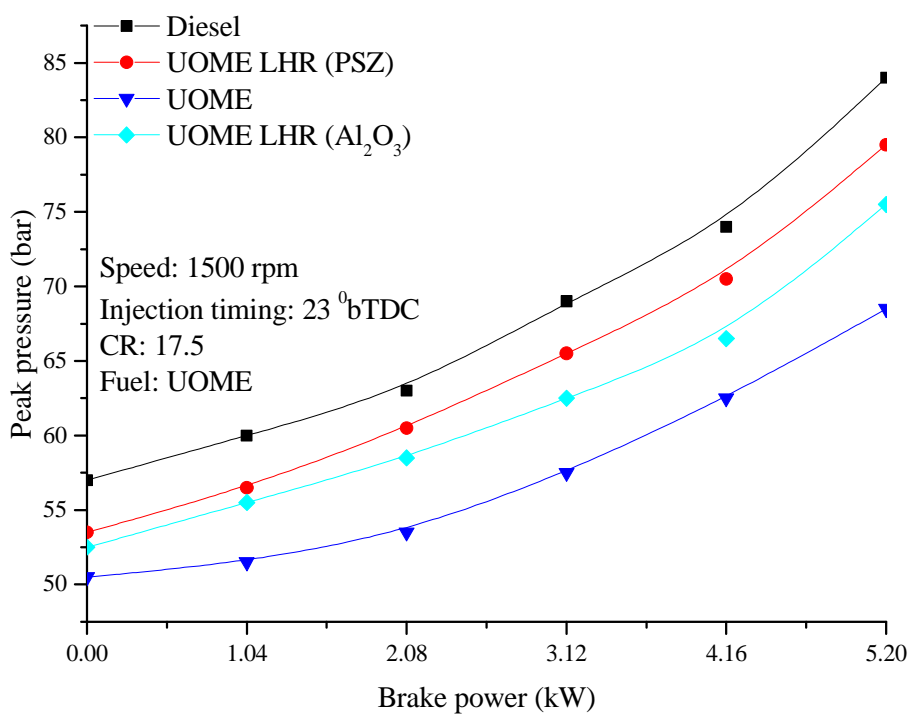

Figure21.Variation of Peak pressure for UOME with TBC

\section{Conclusions}

In the present work, improving the performance of diesel engine fuelled with non-edible derived biodiesel such as UOME and their blends have been undertaken. Experimental investigation results have been carefully analyzed and the following conclusions are made from the observations recorded.

$>$ The differences between saturated and unsaturated fatty acids of vegetable oils play an important role during combustion and in the formation of exhaust emissions. 
> B20 is an attractive option as it improves engine performance significantly with reduced emission levels. Substitution of the indigenous renewable and alternative fuel by fossil improves the country economy. This option is more viable if sufficient nonedible oil seeds are available for biodiesel preparation and cost of biodiesel production are lowered.

$>$ With both PSZ and $\mathrm{Al}_{2} \mathrm{O}_{3}$ coatings the engine brake thermal efficiency is enhanced. Providing TBC is limited to a certain thickness and does not ensure a permanent layer on engine components as it wears out after a long duration of engine operation. This option is most favourable if it can act as a permanent coating.

Performance of diesel engine with biodiesel can be further improved if proper combustion and nozzle geometry is adopted along with blend and TBC selection. However, most biodiesels perform better when torroidal combustion chamber and injector opening pressure more than 210 baris used. Some biodiesels require retarded injection timing while some other advanced injection timing for improved engine performance. Another interesting fact is to develop suitable injector and fuel pump for biodiesel operation. This option needs thorough investigation as each biodiesel is unique and may behave differently when used in diesel engines.

On the whole it is concluded that UOME and their blends operation could be used as an alternative and renewable fuels in diesel engines. Running the engine in single fuel mode with these fuels requires no major modifications in the existing diesel engine.It can be concluded that B20 blended biodiesel with appropriate TBC along with optimized engine operating conditionsas a future work can significantly enhance the biodiesel fuelled engine operation and the performance will then be comparable to diesel engine.

\section{References}

Agarwal A.; Rajamanoharan K., 2009.Experimental investigations of performance and emissions of karanja oil and its blends in a single cylinder agricultural diesel engine, Applied Energy, Vol. 86, pp. 106-112,

Atabani A.E., Silitonga A.S., Ong H.C., Mahlia T.M.I., Masjuki H.H., Badruddin I.A., Fayaz H., 2013. Non-edible vegetable oils: A critical evaluation of oil extraction, fatty acid compositions, biodiesel production, characteristics, engine performance and emissions, production, Renewable and Sustainable Energy Reviews, Vol. 18, pp. 211-245.

Aydin, S., Sayin, C., Aydin, C. 2015. The investigation on the usability of biodiesel obtained from residual frying oil in a diesel engine with thermal barrier coating, Applied Thermal Engineering, Vol. 80, pp. 212-219.

Aydin, S., Sayin, C. 2014. Impact of thermal barrier coating application on the combustion, performance and emissions of a diesel engine fueled with waste cooking oil biodiesel-diesel blends, Fuel, Vol. 136, pp. 334-340, 2014.

Banapurmath, N. R., Tewari P. G., Yaliwal V. S., Kambalimath S., Basavarajappa Y. H.. 2009. Combustion characteristics of a 4stroke CI engine operated on honge oil, neem and rice bran oils when directly injected and dual fuelled with producer gas induction. Renewable Energy, Vol 34, No. 7, pp.1877-1884.

Banapurmath N.R., Tewari P.G., Hosmath R.S., 2008. Experimental investigation of four stroke direct injection diesel engine operated on dual fuel mode with producer gas as a inducted fuel and honge oil and Honge oil methyl ester as injected fuels, Renewable Energy, Vol. 33, No. 9. pp. 2007 - 2018.

Banapurmath N .R,Tewari P. G., 2008. Performance of a low heat rejection engine fuelled with low volatile honge oil and its methyl ester (HOME), Proceedings of the Institution of Mechanical Engineers, Part A: Journal of Power and Energy, Vol. 222, No. 3, pp. 323-330.

Banapurmath N. R., Yaliwal V. S., Kambalimath S., Hunashyal A. M., Tewari P. G., 2011. Effect of wood type and carburetor on the performance of producer gas-biodiesel operated dual fuel engines, Waste and Biomass Valorization, Springer publications, Vol.2, No. 4, pp.403-413. DOI 10.1007/s12649-011-9083-5.

Bajpai S., Sahoo P.K.., Das L.M., 2009. Feasibility of blending karanja vegetable oil in petro-diesel and utilization in a direct injection diesel engine, Fuel, Vol. 88, No. 4, pp. 705-711.

Buyukkaya E., 2010.Effects of biodiesel on a DI diesel engine performance, emission and combustion characteristics, Fuel, Vol. 89, No. 10, pp. 3099-3105.

Buyukkaya E., Engin T., Cerit M., 2006. Effects of thermal barrier coating on gas emissions and performance of a LHR engine with different injection timings and valve adjustments. Energy Conversion and Management, Vol. 47, pp. 1298-1310

Buyukkaya E., Cerit M., 2007. Thermal analysis of a ceramic coatingdiesel engine piston using 3-D finite element method. Surface \& Coatings Technology, Vol. 202, pp. 398-402

Fontaras G, Karavalakis G, Kousoulidou M, Tzamkiozis T, Ntziachristos L, Bakeas E., 2009. Effects of biodiesel on passenger car fuel consumption, regulated and non-regulated pollutant emissions over legislated and real-world driving cycles, Fuel, Vol. 88, No. 9, pp. 1608-1617.

Haşimoğlu C., Ciniviz M., Özsert I., İçingür Y., Parlak A. and Salman M.S., 2008. Performance characteristics of a low heat rejection diesel engine operating with biodiesel, Renewable Energy, Vol. 33, No. 7, pp. 1709-1715.

Hazar $\mathrm{H}$, UgurOzturk, 2010. The effects of $\mathrm{Al}_{2} \mathrm{O}_{3}-\mathrm{TiO}_{2}$ coating in a diesel engine on performance and emission of corn oil methyl ester, Renewable Energy, Vol. 35, No. 10, pp. 2211-2216.

Hüseyin A., İlkılıç C.. 2010. Effect of ethanol blending with biodiesel on engine performance and exhaust emissions in a CI engine, Applied Thermal Engineering, Vol. 30, No. 10, , pp 1199-1204.

Jaichandar, S. and Tamilporai, P., 2003. Low heat rejection engines - an overview. Society of Automotive Engineers, Paper No.: 2003-01-0405, USA. 
Raheman H., Ghadge S.V., 2008. Performance of diesel engine with biodiesel at varying compression ratio and ignition timing, Fuel, Vol. 87, No. 12, pp. 2659-2666.

Rakopoulos C. D., Giakoumis E. G., 2007. Study of the transient operation of low heat rejection turbocharged diesel engine including wall temperature oscillations, Society of Automotive Engineers, Paper No.:2007 -01-1091.

Rakopoulos C.D., Giakoumis E.G., 2006. Second-law analyses applied to internal combustion engines operation, Progress in Energy and Combustion Science, Vol. 32, No. 1, pp. 2-47.

Sahoo B. B., Saha U. K., NiranjanSaho, 2011. Theoretical performance limits of a syngase diesel fueled compression ignition engine from second law analysis, Energy, Vol. 36, No. 2, pp. 760-769.

Singh S. P., Singh D., 2010. Biodiesel production through the use of different sources and characterization of oils and their esters as the substitute of diesel: A review, Renewable and Sustainable Energy Reviews, Vol. 14, No. 1, pp. 200 - 216.

Yaliwal V.S., Banapurmath N.R, Gireesh N.M., Tewari P.G., 2014. Production and utilization of renewable and sustainable gaseous fuel for power generation applications, A review of literature. Renewable and Sustainable Energy Reviews, Vol.34, pp. 608-627.

\section{Biographical notes}

D. N. Basavarajappa is with GMIT, Davangere, Karnataka, India

N. R. Banapurmath is with B.V.B. College of Engineering and Technology, Hubli, Karnataka, India

V. S. Yaliwal is with S.D.M. College of Engineering and Technology, Dharwad, Karnataka, India

G. Manavendra is with BIET, Davangere, Karnataka, India

Received February 2015

Accepted April 2015

Final acceptance in revised form May 2015 